\title{
A Critical Appraisal of Masolo's Non Obligation to Share Wealth: Towards Sustainable Economic Justice in Africa
}

\author{
Mojalefa Lehlohonolo Johannes Koenane
}

\author{
University of South Africa \\ Department of Philosophy, Practical \& Systematic Theology \\ Koenamlj@unisa.ac.za
}

\section{Doi:10.5901/mjss.2014.v5n2p181}

\begin{abstract}
In this paper I look at Masolo's understanding of the African economic justice analytically. In an attempt to understand and engage with Masolo, I look at two aspects among many that characterise Masolo's position and those are Masolo's idea that traditional African system of economic justice or distribution of resources was not practiced irrationally thus suggesting that African communities were conscious and aware of their actions. He further articulates that the act of distributing wealth was not a legal requirement, I argue that the practice may not have been legal requirement if 'legal' for Masolo is used in a Western restricted sense, however, I argue that that the moral calling to the 'right thing' as it were was enough to make the expectation legal. I argue that the material aspect of wealth was inseparable from the spiritual aspect and in this way the origins of wealth were God and the living-dead who participated in the everyday life of the community making others wealthy in order to share their fortune with those less fortunate. Some of the Sesotho expressions and proverbs that will contribute towards the debate are as follows: 'Lebitla la dijo ke mpa', 'metse ho cha mabapa', 'feta kgomo o tshware motho', 'ntja-pedi ha e hlolwa ke phokoje' and 'monyala ka pedi o nyala wa hae'. These expressions directly relates to wealth in the African traditional setting for the Basotho people and I explain them as I use them. There are many more expressions which could have been used but I believe these will suffice.
\end{abstract}

\section{Introduction}

In his chapter on Two Forms of Communitarianism, Masolo rightly points out that the African leaders whose ideas it were to redirect the African people back to African socialism were not philosophers. However, philosophers or not these leaders established the grounds on which philosophers can make sense of what it is to be an African. These leaders were very much aware that they are not philosophers, Kaunda speaking for most of these had this to say: "I certainly do not regard myself as a philosopher permanently enriches the world thought systems, but rather as a practical man confronted with a serious challenge and feeling my way towards a response"1. In his earlier work Masolo supports this idea where he notes that traditional thought is not formulated along theoretical basis but are straight forward beliefs of ordinary people and further argues that theoretical arguments are not a good tool to assess these (1995:133). Certainly these leaders philosophy so to speak was practical and as a result, this practical method will inform the methodology followed in this paper. This paper argues for the idea of traditional African conception of economic justice or the ethical distribution of wealth among African communities. I want to begin my confirming most of what Masolo already recorded in his chapter on the Two Forms of Communitarianism in 'The Self and the Community in a Changing World'. Masolo differentiates between the cultural and political aspect of the African communitarianism. I am not going to dwell on this differentiation but would like to focus on the aspect of wealth that Masolo so well articulates. The reason I wish to focus on this aspect of Masolo's book is simply an interest that I picked up where Masolo articulates that the distribution of wealth was not fulfilling any legal requirement. In his exposition of the traditional communitarian distribution of wealth, Masolo refers to Paul Akoko's idea of communitarianism in what the Zulu people call ukusisela which is the refers to lending the needy neighbour a milky cow.

Masolo uses two concepts which in my opinion were looked at differently by the Zulu and the Basotho communities, firstly, among both the AmaZulu and the Basotho people, there was generally no poor person in a technical sense because of the very practice Masolo refers to of a lending cattle. The idea of poverty was therefore taken care of because wealth was measured in terms of having the cattle and the ability of people to ensure that their neighbours had

${ }^{1}$ Kenneth Kaunda, Letter to My children. 
some kind of feeding. Basically, this supported the idea so well elaborated on by Ramose (2005:100) 'feta kgomo 0 tshware motho'. As a maxim 'feta kgomo o tshware motho'2 simply refers to the idea that when it comes to making a choice between wealth and a needy person who is afflicted by life's difficulties - a traditional Africanist would be called to - to decide against wealth and commit to helping another. Furthermore, this expression emphasises that a person/motho receives priority than wealth or kgomo in this case which is a symbol of wealth/maruo. The ontological grounding of the African worldview is primarily anthropocentric - a person or motho is understood as the centre of existence. This was not because wealth was not desirable but because the African ethical imperative is based on the promotion of life and this promotion of life cultivated the spirit of: mutual care, mutual sharing and mutual aid all of which underline the truth that when one's neighbour is in a state of crisis, there is no way a wealthy neighbour can be sleep peacefully knowing that the situation next door is calling upon him or her to assist. The idea of assisting or caring for the neighbour is that in an African setting one is indeed the neighbour's keeper. In practical terms the message being sent across here is one's trouble is bound to affect one's neighbours as well, this is expressed earlier in Sesotho expression 'metse ho cha mabapa'. According to Ramose (2005:135-136) this practice is characterised as the egoistic expectation from each member of the traditional community to ensure they contribute positively towards a sensible moral obligation to the right to food principle. Trimiew summarises the historical evolution overview of communally-based to individually-based human rights philosophy and writes as follows:

The Western claim for rights was made, taxonomically speaking as species of individual negative rights. The moral agent's claim was for liberty for individuals from constraints of several groups - the state, religion, the family, and the economy. Further this release was the granting of freedom from or liberty from, rather than freedom for or to any particular group, society, or way of life. People were ... free to 'starve to death' (2004:104).

Applying this to individualism that is so encouraged as a new and better way of the self-trying to develop his or her full potential outside the caring environment of traditional African setting, this simply mean that without ubuntu distribution of wealth the self is left to die of starvation or hunger. I grow up in a family in which my maternal uncle (Malome in Sesotho) was quite wealthy with a number of cattle. Although I was not aware of the practice of lending cattle or two to a needy neighbour I knew that every day there was a time of milking. What troubled me as a boy was people would line up and literally say: 're tla lata lebese' meaning we came to fetch milk. The way they said it, it reflected that they have a right to this milk and some would come with big containers. This attitude troubled me but it did not seem to bother my uncle and my cousins who would go as far as taking milk and eggs to a number of households who did not come to collect their share. The same thing happened with eggs. Now that I am old enough to understand, it means that Lebitla la kgomo ke molomo as the Basotho people would put it. In Sesotho to say lebita la kgomo ke motho means that there is only one way to bury food and that is through eating so that food is shared and not spoiled. This is what in Masolo is regarded as the welfare aspect of the traditional African communitarianism. Masolo articulates this practice in my uncle's case thus:

There value of the practice of enabling the poor by providing them some kind of stimulus for self-elevation lies solely in what it produces for others and almost never in self-gain (2010:239).

Two-to-three decades ago, the musical legend Steve Kekane composed a song to this effect saying "O se ke wa lahla bohobe mokgotsi, hobane ba bangata ba ya bohloka". Do not throw away bread since most need that bread. All of the above statements confirm that wealth was always to be shared in the community.

\section{African Wealth, Economic Ethics and Badimo}

In African the idea of wealth is inseparable to the idea of Badimo, Amadlozi or the living-dead who with their participation in the events and activities of their communities are ever presence in the African economic system. In articulating the role of the living-dead (which Masolo refers to as ancestors), he contends the reality that the living dead though invisible are active in the community events (2010:234). For Masolo the people living in the here-and-now continue as it were the life expected of them by God and the living-dead. In this sense the African economic ethics incorporates deep spirituality. Masolo does not dwell on this aspect of the communitarian life. The point is better expressed in Gyekye who argues that traditional Africa religion is also materialistic:

The acquisitive, capitalistic element of the African character, the hankering after material welfare, the appreciation of

2 The Sotho idea of 'feta kgomo o tshware motho has been popularised by Ramose in most of his writings. 
wealth and material success; all these attitudes have reverberations in the African conceptions and practice of religion. In African traditional conceptions, religion is to be pursued also for its social or material relevance [...] the munificence of the gods was to be exploited for human well-being in the world (1997:155).

Looked at from this perspective, material wealth in the African worldview is always perceived as divine. Individuals are blessed with plenty in order for them to bless others. To be blessed with plenty of wealth means that the entire community must benefit or share in this fortune. Coming to others assistance in time of need mainly focus on assisting those less fortunate. Based on this approach, we believe that the African communitarian outlook was primarily a welfare approach and being kind to others and allowing them to share in one's fortune was never a big deal in rural African communities. This is better expressed by Oosthuizen, (1991:35) who argues that in traditional African worldview, people are surrounded by other beings. Masolo rightly argues that this was not a legal requirement but it was a moral call on the conscious of those fortunate but primarily an expectation first and foremost from fortunate members of one's family. I am curious about how Masolo understand this legal requirement since the African understanding of the legal requirement is not necessarily the same as the Western understanding of the same. This is because in my own understanding, the moral obligation to look after the less fortunate was indeed binding; in which case what is morally binding in one's conscious is binding. Perhaps for this we need to look at Ramose's analysis of According to Matshela, what he refers to as maruo in Sesotho (wealth in the dominant language of power) was indeed understood the same way Masolo explains, that is in terms of sharing and taking care of those less fortunate among us. Interpreting Nyerere, Masolo maintains that while taking care of others or in "acting with regard for others' welfare", gives the idea that there must be something [...] and further argues that that something would be compromised. My taking of Masolo's statement is that whether we take action or do nothing, there are consequences; God and the living-dead put more responsibility on those of us who are blessed with wealth and that responsibility means that sharing with others is the highest call for those with plenty so that the gap between the 'have', and 'have not' is not visible like in the Lockean individual property ownership. Oosthuizen writes thus: "to be blessed implies having children and food, and to be healthy, but this is the case only if the whole community shares in it" (Oosthuizen in Olupona, 1991:41). This emphasises the welfare aspect of the African economic system.

In this sense, for Masolo there is a connection between his idea of morality and the ontological order. Masolo (2010:239) rightly points out that the idea of the lending cattle was not something just done with closed eyes - he further makes a point which I find exciting, Masolo argues that the economic distribution among these traditional African people is not as if it is something irrational - he argues that these welfare actions are rational actions well thought of and reflected upon, in this way, the traditional African welfare approach inherently rational. Masolo (2010:239) rightly points out that the idea of the lending cattle was not something just done with closed eyes - it was putting extra ordinary obligation on the one receiving cattle, obligation here means full participation in community matters and fulfilling one moral obligations in other avenues within the community. Therefore the burden was placed on the person receiving aid to prove that they are deserving of such aid. On the other hand, failing to assist and alleviate poverty was in an African context regarded as failing in one's moral obligation, and this was also regarded as injustice on the part of the one with plenty. There were measures in place to ensure compliance or paying the consequences. Masolo forgot to mention that one of the consequences in failing to comply with the community expectations was the fact that a lending person may even be obliged to recall or take back his cattle without notice. This was done to express disappointment on a receiving persona non-grata.

Wealth/maruo as Sesotho referred to being blessed with resources such as land, cattle, sheep, goats, pigs, chickens and many other animals which characterised one as having plenty. By its very nature, the traditional understanding of African communitarianism meant that in reality no individual owned anything individually as in the Western worldview. The cow is not owned but only allows its products to be used for the enhancement of human life for everyone in the community. The idea of the milky cow which Africans share with the needy neighbour, is discussed in Masolo, however, I think although the example is good and reflects the truth - I believe the emphasis on the distribution of material wealth does not suffice to bring home the deep meaning of such an exchange, I believe it is not only the material exchange that mattered but also more the participation in the activities of the community. The needy person who receives such aid from other community members was in return expected to fully participate in the activities of the community, failing to do a person was ostracised by the community in such a way that he or she is regarded as a loner. Becoming a loner and being regarded as inkomo idla yodwa (isiZulu proverb expressing the idea of a cow that grazes on its own) is the worst experience and punishment in the African context.

Among traditional people, the reality about marriage is that it has an economic value, this is the fact that we cannot deny, especially in the modern times. This section discusses this economic value within the parameters of economic 
justice. Marriage was always considered an important aspect of traditional African life for a simple reason that marriage was associated with child-bearing. However, the idea of ilobolo/mahadi was then introduced but not for its economic value but as a way of establishing that the young man who proposes to marry someone else's daughter will be able to take care of her once he has removed her from her parents care. I need to make it clear that African do not translate ilobolo or mahadi as bride-price because it is not a price, as such we give ilobolo we do not pay ilobolo. But for purposes of this paper I will leave that for another time. It must be mentioned here that the original idea would be to give about 15 cattle for ilobolo or more, however, a fact that a person may not have 15 cattle did not mean that a person did not have the right to marry as a result the Basotho people had an expression 'monyala ka pedi o nyala wa hae', basically meaning even with as little as two cattle one can easily get married. In this case the Bantu people of Basotho culture understood the fact that if marriage was something that could only be a right of those who are with plenty of cattle then there would be disaster for people with out or as Karl Marx puts it, for the 'have not', therefore, for the Bantu people it did not matter whether a person was rich or not marriage was a right and as such this right basically supported the idea of the promotion of life through bringing children to this world.

The idea of Mbuya Akoko which Masolo (2010:239) uses where people would 'chip in' as it were is rather different in the Sesotho and isizulu contexts. Under these contexts, in every family the father will ensure that he prepares for the day when his son will express the wish to get married. Usually, as early as when the child is growing up, there are cows that are transferred to him (ho tshwaelwa in Sesotho) 'ukusiselwa' in isizulu, and from the time these are transferred they are his - he can dispose of them as he wishes. It may still happen that these are not enough when the young man wants to get married - it is then the parents to begin with will assist. The young man will tell the father and the father will ask the question: how many cattle do you have and during the lobolo/mahadi process the father will add on a certain number of cattle depending on how many were required. It is in such cases amaZulu will talk of izinkomo zikababa or the Basotho people expression of dikgomo tsa ntate. This basically refers to the fact that the cattle that settled the lobolo/mahadi for the new wife came from the father. But the expression 'monyala ka pedi o nyala wa hae' captured the situation where such assistance was not possible. This made true another Sesotho expression that says: 'Ntja-pedi ha e hlolwe ke phokoje', meaning together we conquer. Therefore, the idea of ho tshwaelwa or ukusiselwa served an economic reward and uplifting of a child when he is growing up it was also a form of a traditional inheritance which took place before the death of parents. This also accommodated the girl-child who will also get their share of the cattle before they leave their parents' home. However, to protect the girl-child from being cheated, she will get her share of the cattle after she gets married and these she can also dispose of as she pleases. This was in and among the Basotho and amaZulu legally binding - it may not as I suggested earlier follow the Western restricted idea of 'legally requirement' but nevertheless it was still binding. Again the Basotho proverb 'monyala ka pedi o nyala wa hae' outlines the fact that not all families had plenty cattle and as such the right to marriage is not impeded by one's unfortunately state of affairs. The expression 'monyala ka pedi o nyala wa hae' further establishes a ground where the poor's right to marriage is protected. This further characterises marriage as a communal thing, a wife now belongs to the extended family of his husband which assisted their son in organising both the lobolo/mahadi and negotiate for their son. The negotiations are a platform where the relatives are seriously engaged into finalising this process. The significance of the communal support for the economic survival of the individual is without measure because without it, the individual is nothing and has nothing. The above points to a welfare approach designed towards sustainable economic development through traditional methods of communitarianism.

\section{The Practice of Ho Tshwaelwa or Ukusisela}

In the preceding pages I detailed the practice of ukusisela or ho tshwaelwa in Sesotho; (i.e. transferring of live-stock to children. I now wish to go deeper into how this system ensured individual economic independence. Ukusisela or ho tshwaelwa system was a tool through which economic independence was ensured for both boys and girls. Contrary to the belief that the system only looked at the interests of boys, the system of ho tshwaelwa facilitated that both females and males are taken care of. Traditional African setting was conscious of the unknown future and as such they prepared well for it. Not only live-stock was marked or transferred to children, land for agricultural purposes was also considered as a way of transferring wealth. So much as this was said to be a communal land, it was still under the control of a given family - who will dispose of it as they please (Koenane, 2012). Both live-stock and land had serious economic effects. Land and live-stock could be transferred to both children and strangers who worked or assisted in a homestead. The transferring did not occur automatically both children and workers had to earn it - again this emphasises the point brought by Masolo that the practice of lending a cattle was not done unconsciously or irrationally. This also answers the 
question that providing for the less fortunate meant encouraging laziness - even among African there was no free lunch. In this way there were two moral ways through which wealth could be accumulated:

- Ho tshwaelwa/ukusisela (which was as explained not limited to one's own blood relatives), but could be extended to outsiders as well. I further explained that this was not automatical - it only was allocated to people who displayed certain moral traits and work ethic.

- Direct inheritance (amafa/mafa) which was limited only to blood relatives, most of the time it was automatic and had its problems and ethical dilemmas, and

These two ways had their three ethical dimensions which I will not expand on but only mention in passing. The ethical dimensions can be summarised as follows: The two ways to accumulate wealth was meant for individuals to be economically independent, to have sustainable methods for economic growth and finally these were means of a sustainable economic development that was supported by one's community in particular the family and sometimes even the extended family. This also makes true the idea aphorism 'motho ke motho ka batho'. We believe that economic justice in the African context addresses the problem of economic distribution whereas, globalisation addresses the question of redistribution, and the two are completely different. Murove concludes as follows in his discourse about a sound economic ethics: "Contemporary African discourses on economic development are moving beyond the [...] to seek indigenous values that might allow the spirit of a new culturally relevant form of capitalism to flower in Africa".

\section{Conclusion}

In view of the points made so far, it is important to mention that the traditional economic justice is inevitably different from the Western conceptions of the same which is fundamentally grounded on individualism and it is further characterised by competition. Therefore, we thus come to the conclusion that this natural-conflict in terms of which experience emanating from changing experiences of the self are frameworks that speaks to different modes of identity namely the western morality and the traditional African ethics are not just abstract worldviews but are of practical significance in line with the African metaphysical worldview. In terms of this worldview, the African understands him or herself as primarily belonging to the community and thus finding that his/her life makes sense when participating in the communal events.

As much as the points made in this paper unpack how the African worldview accounts for its economic distribution, we cannot pretend as if things have not changed. Therefore, in the light of these changes the African needs to ensure that there promotion of life is positioned in such a way that the African does not ignore cultural and political changes that calls for adaptions in the contemporary world. We cannot romanticise the traditional way of life even when we see it does not have a chance against the liberal individualistic and capitalistic outlook. I believe that African with its communitarian worldview can contribute towards making the world a better place with its welfare approach. Certainly, African communitarianism may not necessarily resolve or correct the fundamentally distorted economic system through globalisation but can serve as a point of departure to close the gap that is widening every day. At least some of the principles that held traditional African people together must be preserved and incorporated in the contemporary economic strategies and be tried out. The way to close the gap between the 'have' and those without is only by encourage the only worldview which makes economic sense in its economic and resource distribution and that is the traditional African communitarianism as Masolo suggests. I wish to conclude by quoting Mvume Dandala statement, for its relevance to this paper, he writes: "Ubuntu could transform economic practices and make African economies as competitive as any other that have transformed themselves by discovering the fundamental values of their social context" (2009:262).

\section{References}

Dandala, M.H. (2009). 'Cows Never Die: Embracing African cosmology in the Process of economic Growth'. In M.F. Murove (ed.), African Ethics: An Anthology of Comparative and Applied Ethics. Pietermaritzburg: UKZN Press.

Gyekye, K. (1997). Tradition and Modernity: Philosophical Reflections on the African Experience. New York, Oxford: Oxford University Press.

Kaunda, K. (1973). Letter to my Children. London: Longman.

Koenane, M.L.J. (2011). Ubuntu Values for Effective HIVIAIDS Prevention in South Africa: Western and African Medical Perspectives Together in dialogue. Germany, Saarbrucken: Lambert Academic Publishing.

Masolo, D.A. (1995). African Philosophy in Search of Identity. Nairobi: East African Educational publishers.

Masolo, D.A. (2010). Self and the Community in a Changing World. Bloomington and Indianapolis: Indiana University Press.

Matshela, Z.A. (1990). Bochaba Ba Basotho. Mazenod-Lesotho: Mazenod Publishers.

Murove, M.F. (2009). 'The Quest for an African Economic Ethic'. In M.F. Murove (ed.), African Ethics: An Anthology of Comparative and 
Applied Ethics. Pietermaritzburg: UKZN Press.

Oosthuizen, G.C. (1991). "The Place of Traditional Religion in Contemporary South Africa". In J.K. Olupona, (ed.). In African Traditional Religions in Contemporary Society. Minnesota: A New Era Book, Paragon House.

Ramose, M.B. (2005). African Philosophy through ubuntu. Harare, Zimbabwe: Mond books Publishers.

Trimiew, D.M. (2004) 'Ethics: moral Evolutions from Customary Societies to Atomistic Individuals'. In Handbook of US Theologies of Liberation, (ed.), M.A. de la Torre. St Louis: Chalice Press. 